\title{
Irrigation Water Management Practices in Smallholder Vegetable Crops Production: The Case of the Central Rift Valley of Ethiopia
}

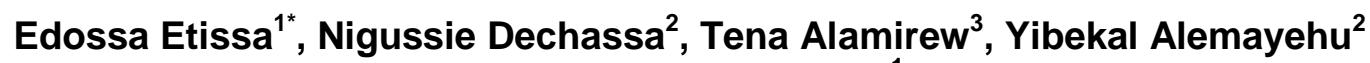 \\ and Lemma Desalegne ${ }^{1}$
}

\author{
${ }^{1}$ Agronomy and Horticulture, Ethiopian Institute of Agricultural Research (EIAR), Melkassa Agricultural \\ Research Center, Post Box No: 436, Adama, Ethiopia \\ ${ }^{2}$ College of Agriculture and Environmental Sciences, Haramaya University,Dire Dawa, Ethiopia \\ ${ }^{3}$ Water and Land Resources Centre, Rahem Building, Diaspora Square, Megenagna, Addis Ababa, Ethiopia
}

\begin{abstract}
Smallholder irrigated vegetable production in the Central Rift Valley region of Ethiopia is instrumental in ensuring the year-round availability of fresh vegetables in the local market in the country. However, a number of problems constrain irrigated vegetable production in the region. Therefore, asurvey was conducted with the objectives of assessing smallholder irrigated vegetable production practices and identifying factors associated with problems of irrigation water management. The survey was conducted in December 2011. A multistage purposive sampling procedure was employed to select sample districts, peasant associations, and sample respondents that grew vegetables using small-scale irrigation. Key informants were interviewed and group discussions were conducted with smallholder vegetable farmers. Data were collected on household irrigation knowledge, experiences, skills, irrigation water sources as well as on irrigation water management practices such as methods, time, depth and frequency of irrigation. Data were also collected on supplemental irrigation practices under rain-fed vegetable production. In addition, household perceptions on the environmental impacts of irrigation, on-farm irrigation water related challenges, and related information were also recorded. About $16.5 \%$ of the respondents indicated that their knowledge and skills on irrigation water management practices were mainly drawn from experiences of trial and error.About $38.1 \%$ of the respondents indicated that they irrigated their vegetable fields both in the morning and the afternoon whereas $35.1 \%$ replied that they irrigated only in the afternoon. A large number of the respondents (89.6\%) replied that they determined irrigation intervals based on specific crop needs. About $90.9 \%$ of the respondents replied that they applied enough irrigation water up to the point where the water level reached the furrow basin head. The survey result also indicated that $51.7 \%$ of the respondents practiced supplemental irrigation when shortage of moisture occurred in the soil during the rainy season as well at the end of the rainy season. One hundred percent of the respondents replied that they faced problems commonly related with the use of irrigation, namely, soil salinity, waterlogging, soil erosion and degradation, sedimentation, and build-up of pests and diseases. In conclusion, the survey results revealed that extension services on irrigation water management were almost non-existent, and the smallholder vegetable farmers managed irrigation water merely by intuition.Therefore, participatory on-farm irrigation research and extension on irrigation water management practices should be formulated to generate appropriate technologies for
\end{abstract} enhanced and sustainable irrigated vegetable production in the region.

Article Information

Article History:

Received :15-01-2014

Revised : 17-03-2014

Accepted : 22-03-2014

Keywords:

Smallholders

Irrigation

Vegetable crops

Central Rift Valley

Ethiopia

*Corresponding Author:

Edossa Etissa

E-mail:

edossa.etissa@gmail.com Copyright@2014 STAR Journal. All Rights Reserved.

\section{INTRODUCTION}

Since the start of vegetable research in Ethiopia, a lot of production packages have been developed for major vegetable crops in the Central Rift Valley (CRV) region of Ethiopia (Lemma, 2002; Lemma, 2004; Lemma and Shimelis, 2003; Edossa, 2014). Furthermore,a number of changes have occurred in vegetable production practices in the region, including introduction of new cultural practices such as high density planting and intensive use of inputs (fertilizers, fungicides and other chemicals)
(Edossa et al., 2013a; Edossa et al., 2013c; Edossa et al., 2013d; Edossa, 2014). Commercial irrigated agriculture was started in the Rift Valley corridor of the country. With the passage of time, the semi-pastoral households inhabiting the region adopted cultivation of high value vegetable crops using various sources of irrigation water. Nowadays, vegetable production as a business has reached a climax in the area in which hundreds of thousands of farmers (households, sharecroppers, 
Edossa et al.,

investors), brokers, and various forms of traders are involved (Edossa, 2014).

However, improving production and productivity of vegetable crops significantly depends on the extent of availability of improved field production packages and application of the packages to vegetable production by farmers (Edossa, 2014). Enhanced vegetable crops production requires the use of improved production packages such as high-yielding vegetable varieties, improved seed, optimum seeding rates, spacing, tillage, and frequency of irrigation. However, there is dearth of information on on-farm vegetable production systems particularly irrigation water management practices. Therefore, there was a need to assess household irrigation water management practices in vegetable production systems under both rain-fed and irrigated conditions with the participation of vegetable-producing farmers. Thus, a survey was conducted to diagnose the problems associated with irrigated vegetable production and to elucidate constraints and opportunitiesirrigation water management practices in the central rift valley region of Ethiopia.The results of the diagnosis could be used to help in identifying major factors that limit farm water productivity and recommending possible improvements through policy interventions (CIMMYT, 1998).

\section{MATERIALS AND METHODS}

\section{Description of the Study Area, Sample Size and Method of Sampling}

The survey included smallholder vegetable growers in the Awash River Basin. The rift valley closed catchment basins were chosen as the study area because they good potential for irrigated vegetable production. The households living along the Awash River and near the rift valley lakes have long experiences in vegetable production. However, there is similarity among the sample districts in terms of climate, geology, vegetation. There are also variations in terms of source and status of irrigation water and use, with more advanced use in MekiZiway area.

The Central Rift Valley (CRV) region of Ethiopia is dominantly a flat topography stretching from Modjo-Koka to Boora-Meki-Ziway, with alacustrine cover and alluvial soil deposits (Behailu, 2007). Boring even a very shallow hole would strike water. Almost every farm household in the area possesses water holes. However, with little land suitable for gravity-type irrigation development, most traditional household schemes use motor pumps for lifting water at head, and most irrigation water users along the river banks and lakeshores are compelled to use and maintain costly water pumps.

The detailed "materials and methods"are described in the previously published paper titled "Household Fertilizer Use and Soil Fertility Management Practices in Vegetable Crops Production: The Case of Central Rift Valley of Ethiopia", STAR Journal by same authors (Edossa et al., 2013b) 2013, 2(4): 47-55.
Sci. Technol. Arts Res. J., Jan-March 2014, 3(1): 74-83

\section{RESULTS AND DISCUSSION}

Sources of Irrigation Practices and Knowledge of the Smallholder farmers

Sources of Irrigation Knowledge and Practices

From among among respondents, $16.48 \%$ replied that the knowledge source of their irrigation management packages was from experience whilst $12.08 \%$ replied that the knowledge sources were both experience and forefathers. These results indicated that growers drew knowledge and skills of irrigated vegetable production merely from informal sources, with little indication of support from the formal scientific system such as research (Table 1). Smallholder farmers did not indicate that their irrigation scheduling was supported by improved irrigation technologies. The farmers indicated that knowledge source from both extension agents and from fellow farmersaccounted only $9.99 \%$. After reviewing two small scale irrigation schemes known as Haleku and Golba I in the CRV area, Paas (2010) concluded that irrigation water users/ vegetable growers should be provided with knowledge and tools to warrant sustainable development. Currently, each peasant association (PA) has three development agents (Das): one in crop production, one in animal production and a third in natural resources management; irrigation water management is under the natural resources management; however, it is beyond the capacity of DAs. There are many reports explaining that extension workers lack adequate and appropriate technical and communication skills (Getachew and Mohammed, 2012)though efforts are underway by the Ministry of Agriculture (MOA) to upgrade their technical skills through training (Mengistu, 2008). Based on the various group discussions, development agents (DAs) are also overloaded with activities such as tax collection, mobilizing farmers for public campaign work, collecting loan repayments and others (Getachew and Mohammed, 2012). The survey results of this study indicated that extension services on irrigation were non-existent in the region. Thus, in order to improve knowledge and skills of farmers in irrigated vegetable production, due attention should be given to enhancing extension services on irrigation and drainage management.

\section{Availability of Irrigation Package}

Based on farmers' perception, $91.66 \%$ of the growers responded that they have irrigation water management packages (how much and when to irrigate) for their vegetables they produce. However, $7.29 \%$ indicated that they did not have irrigation package (Table 2). However, for farmers claiming that they have irrigation packages, the irrigation package are not based on scientific knowledge. For most of them, irrigation package meant merely diversion of water to vegetable fields through furrows.

Absence of irrigation extension services indicates that the household vegetable production systems are not monitored and evaluated. Consistent with the results of this survey, Gulilat (2002) summarized that the traditional irrigation development in Ethiopia is highly characterized by many problems, uncertainties and ambiguities in irrigation planning with unskilled labour, low-tech intensive investment, and lack of sustainable and reliable water resources management strategy and lack of stakeholder participation. 
Table 1:Sources of vegetable irrigation practices and knowledge for smallholder households

\begin{tabular}{|c|c|c|c|c|c|c|c|c|}
\hline \multirow{2}{*}{$\begin{array}{c}\text { Sources of irrigation } \\
\text { practices and knowledge }\end{array}$} & \multicolumn{2}{|c|}{ High income } & \multicolumn{2}{|c|}{ Medium income } & \multicolumn{2}{|c|}{ Low income } & \multicolumn{2}{|c|}{ Total } \\
\hline & No. & Percent & No. & Percent & No. & Percent & No. & Percent \\
\hline None & 4 & 22.22 & 1 & 2.38 & 3 & 9.67 & 8 & 8.79 \\
\hline From family (1) & 0 & 0 & 3 & 7.14 & 2 & 6.45 & 5 & 5.49 \\
\hline From experience (2) & 0 & 0 & 10 & 23.80 & 5 & 5.16 & 15 & 16.48 \\
\hline From extension agent (3) & 2 & 11.11 & 6 & 14.28 & 1 & 3.22 & 9 & 9.89 \\
\hline From fellow farmers (4) & 1 & 5.55 & 6 & 14.28 & 2 & 6.45 & 9 & 9.89 \\
\hline From Research Centres (5) & 0 & 0 & 0 & 0 & 1 & 3.22 & 1 & 1.09 \\
\hline $\begin{array}{l}\text { From private producers } \\
\text { coming from other area }(6)\end{array}$ & 0 & 0 & 2 & 4.76 & 0 & 0 & 2 & 2.19 \\
\hline Obtained from NGO (7) & -- & -- & -- & -- & -- & -- & -- & -- \\
\hline Obtained fromcooperatives (8) & -- & -- & -- & -- & -- & -- & -- & -- \\
\hline All (9) & 2 & 11.11 & 3 & 7.14 & 1 & 3.22 & 6 & 6.59 \\
\hline 2 and 3 & 1 & 5.55 & 3 & 7.14 & 3 & 9.67 & 7 & 7.69 \\
\hline 1 and 2 & 4 & 22.22 & 2 & 4.76 & 5 & 16.12 & 11 & 12.08 \\
\hline 1,2 and 3 & 1 & 5.55 & 3 & 7.14 & 1 & 3.22 & 5 & 5.49 \\
\hline 5 and 7 & 1 & 5.55 & 0 & 0 & 0 & 0 & 1 & 1.09 \\
\hline 2 and 5 & 2 & 11.11 & 0 & 0 & 1 & 3.22 & 3 & 3.29 \\
\hline 3 and 6 & 0 & 0 & 1 & 2.38 & 1 & 3.22 & 2 & 2.19 \\
\hline 2 and 4 & 0 & 0 & 1 & 2.38 & 2 & 6.45 & 3 & 3.29 \\
\hline 1,2 and 4 & 0 & 0 & 1 & 2.38 & 2 & 6.45 & 3 & 3.29 \\
\hline 1 and 6 & 0 & 0 & 0 & 0 & 1 & 3.22 & 1 & 1.09 \\
\hline Total & 18 & 100 & 42 & 100 & 31 & 100 & 96 & 100 \\
\hline
\end{tabular}

Table 2:Availability of household vegetable growers' irrigation packages.

\begin{tabular}{ccccccccc}
\hline Availability of & \multicolumn{2}{c}{ High income } & \multicolumn{2}{c}{ Medium income } & \multicolumn{2}{c}{ Low income } & \multicolumn{2}{c}{ Total } \\
\cline { 2 - 9 } irrigation package & No. & Percent & No. & Percent & No. & Percent & No. & Percent \\
\hline None & 1 & 5.26 & 0 & 0 & 0 & 0 & 1 & 1.04 \\
Yes & 15 & 78.94 & 44 & 97.77 & 29 & 90.62 & 88 & 91.66 \\
No & 3 & 15.78 & 1 & 2.22 & 3 & 9.37 & 7 & 7.29 \\
\hline Total & $\mathbf{1 9}$ & $\mathbf{1 0 0}$ & $\mathbf{4 5}$ & $\mathbf{1 0 0}$ & $\mathbf{3 2}$ & $\mathbf{1 0 0}$ & $\mathbf{9 6}$ & $\mathbf{1 0 0}$ \\
\hline
\end{tabular}

Several studies of small scale irrigation in Ethiopia (Birhanu, 2006; Birhanu and Tilahun, 2010; Abiti, 2007; Mekuria, 2003; Carter and Danert, 2006; and Paulos, 2002) identified that the main constraints facing small scale household irrigation water users are lack of knowhow, and access to opportunities of irrigation technology; and weak extension services. Carter and Danert, (2006) and Mengistu (2008) stressed that farmers' knowledge and practices in water management should be the first area of field research priorities. Thus, expanding irrigable areas in the dry land (like Fantalle Large Scale Irrigation Scheme) without developing proper irrigation management practices and imparting them onto the producers might damage the ecosystem irreparably.

Similarly, Mekuria (2003) reported that there was poor institutional structure in place to support farmers in planning and budgeting irrigation water management and crop water requirement at farm levels. Desta (2004) also found that smallholder farmers in west Shoa have limited access to technology and institutional services.

\section{Irrigation Water Sources and Uses}

Irrigation Water Sources:Among the vegetable growers, $36.73 \%$ reported to have used water diverted from rivers and $34.69 \%$ reported to have used water from hand-dug wellsand boreholes (Table 3). The major irrigation water sources for vegetable crops production in the area are diversion and pumping from rivers, lakes, and shallow wells. Thus, many vegetable growers have motor pumps for lifting water that is supplied to vegetable crops in fields through the furrow irrigation methods.

The upper sample areas/ districts are rich in underground water reservoirs. Because of the proximity of the production areas to rivers, the lakeshores and other water sources, vegetable acreage has been expanding to wider places far from the water sources. The water is pumped from boreholes. However, use of groundwater for irrigation has increased increases from season to season. This trend would pose challenges to the sustainability of underground waterdue to absence of practical water management guidelines.

Diversions irrigation sources dominate along the Awash River, Adaama, and Boosat districts whereas the use of ground water dominates in Dugida, Boorra and Adamii Tullu J/K districts (Table 4).

Irrigation Water Uses: It is estimated that higher percentage of vegetable growers use their own (borehole) water sources whilst an equal percentage of low income group replied that they use irrigation water from both sources (Table 5). Farmers who use their own water sources replied they have their own water pumping motors for lifting water from lakes, rivers, or boreholes. 
Table 3: Irrigation water sources of sample household cultivating vegetables in the study area.

\begin{tabular}{lcccccccc}
\hline \multirow{2}{*}{$\begin{array}{c}\text { Irrigation water } \\
\text { sources }\end{array}$} & \multicolumn{2}{c}{ High income } & \multicolumn{2}{c}{ Medium income } & Low income & \multicolumn{2}{c}{ Total } \\
\cline { 2 - 8 } & No. & Percent & No. & Percent & No. & Percent & No. & Percent \\
\hline Diversions from river (1) & 4 & 21.05 & 22 & 48.88 & 10 & 29.41 & 36 & 36.73 \\
From diversions from spring (2) & 0 & 0 & 1 & 2.22 & 0 & 0 & 1 & 1.02 \\
From RWH (3) & - & -- & -- & -- & -- & - & - & - \\
Pump from lake (4) & 2 & 10.52 & 4 & 8.88 & 7 & 20.58 & 13 & 13.26 \\
Hand dug well and borehole (5) & 8 & 42.10 & 14 & 31.11 & 12 & 35.29 & 34 & 34.69 \\
1 and 5 & 3 & 15.78 & 3 & 6.66 & 2 & 5.88 & 8 & 8.16 \\
4 and 5 & 2 & 10.52 & 1 & 6.66 & 1 & 2.94 & 4 & 4.08 \\
1 and 4 & 0 & 0 & 0 & 0 & 1 & 2.94 & 1 & 1.02 \\
Others & 0 & 0 & 0 & 0 & 1 & 2.94 & 1 & 1.02 \\
\hline Total & $\mathbf{1 9}$ & $\mathbf{1 0 0}$ & $\mathbf{4 5}$ & $\mathbf{1 0 0}$ & $\mathbf{3 4}$ & $\mathbf{1 0 0}$ & $\mathbf{9 8}$ & $\mathbf{1 0 0}$ \\
\hline
\end{tabular}

Table 4:Household irrigation water sources for vegetable crop production in sampled districts in the study area.

\begin{tabular}{lccccccc}
\hline \multirow{2}{*}{ Irrigation water sources } & \multicolumn{7}{c}{ Sample districts } \\
\cline { 2 - 8 } & Boosat & Adaama & Luume & Dugidaa & Boora & A/T/J/K & Total \\
\hline Diversions from river (1) & 18 & 12 & 3 & 1 & 0 & 2 & 36 \\
Diversions from spring (2) & 1 & 0 & 0 & 0 & 0 & 0 & 1 \\
Pump from lakes (3) & 0 & 0 & 0 & 4 & 0 & 9 & 13 \\
Hand dug well and borehole (4) & 0 & 5 & 9 & 7 & 10 & 4 & 35 \\
1 and 4 & 0 & 2 & 4 & 0 & 1 & 2 & 9 \\
3 and 4 & 0 & 0 & 1 & 3 & 0 & 0 & 4 \\
\hline Total & $\mathbf{1 9}$ & $\mathbf{2 0}$ & $\mathbf{1 7}$ & $\mathbf{1 5}$ & $\mathbf{1 1}$ & $\mathbf{1 7}$ & $\mathbf{9 9}$ \\
\hline
\end{tabular}

Table 5: Irrigation water use system of household vegetable growers in the study area.

\begin{tabular}{lcccccccc}
\hline & \multicolumn{2}{c}{ High income } & \multicolumn{2}{c}{ Medium income } & \multicolumn{2}{c}{ Low income } & \multicolumn{2}{c}{ Total } \\
\cline { 2 - 9 } & No. & Percent & No. & Percent & No. & Percent & No. & Percent \\
\hline Own (1) & 11 & 64.70 & 21 & 47.72 & 14 & 46.66 & 46 & 50.54 \\
Communal (2) & 5 & 29.41 & 17 & 38.63 & 14 & 46.66 & 36 & 39.56 \\
1 and 2 & 1 & 5.88 & 6 & 13.63 & 2 & 6.66 & 9 & 9.89 \\
\hline Total & $\mathbf{1 7}$ & $\mathbf{1 0 0}$ & $\mathbf{4 4}$ & $\mathbf{1 0 0}$ & $\mathbf{3 0}$ & $\mathbf{1 0 0}$ & $\mathbf{9 1}$ & $\mathbf{1 0 0}$ \\
\hline
\end{tabular}

The proliferation of smallholder private irrigation is largely spontaneous, anarchic, and unregulated. Some consider it land grabbing from smallholder subsistence farmers on contractual basis. Despite its own advantage, this trend also poses the problem of inequity, gender inequality, inefficiency, and environmental degradation. The uncontrolled proliferation of small pumps irrigation water can also lead to environmental damage. Ground water depletion and conflicts between upstream and downstream water users are also the other problems.

Agricultural use of groundwater is rising due to shallow to very shallow water table along the lake shores and rivers and availability of various sizes of water pumps in the study area. Groundwater irrigation provides potential employment opportunities, particularly during the long dry season in the CRV area of the country.

\section{Pump Ownership, Methods, and Time of Irrigation}

Among the sample vegetable growers, $68.36 \%$ reported that they have their own water pumps whilst
$31.63 \%$ have no water pumps (Table 6 ). The farmers also stressed that low price water pumps have high maintenance costs.

Methods of Irrigation: In the study area, vegetable production is carried out mainly under furrow irrigation. Almost $98.97 \%$ of all householdvegetable growers use furrow method of irrigation. However a very small percentage $(1.02 \%)$ used flood irrigation in the study areas (Table 7). Lifting water by small pumps from different sources to the farm and then irrigating vegetable fields by gravity through narrow furrows (for onion) and broad bed furrow (for tomato) traditional irrigation types are the most common irrigation methods. Many referencesare available (Bos et al., 2009) that, together with poor flow control, furrow irrigation leads to low uniformity of water application and the field application ratio is often less than $40 \%$, rendering it the least efficient water application method.

Table 6: Water pump ownership of the household vegetable growers.

\begin{tabular}{lllllllll}
\hline \multirow{2}{*}{$\begin{array}{c}\text { Pump } \\
\text { ownership }\end{array}$} & \multicolumn{2}{c}{ High income } & \multicolumn{2}{c}{ Medium income } & \multicolumn{2}{c}{ Low income } & \multicolumn{2}{c}{ Total } \\
\cline { 2 - 9 } & No. & Percent & No. & Percent & No. & Percent & No. & Percent \\
\hline Yes & 16 & 84.21 & 27 & 60 & 24 & 70.58 & 67 & 68.36 \\
No & 3 & 15.78 & 18 & 40 & 10 & 29.41 & 31 & 31.63 \\
\hline Total & $\mathbf{1 9}$ & $\mathbf{1 0 0}$ & $\mathbf{4 5}$ & $\mathbf{1 0 0}$ & $\mathbf{3 4}$ & $\mathbf{1 0 0}$ & $\mathbf{9 8}$ & $\mathbf{1 0 0}$ \\
\hline
\end{tabular}

Table 7: Irrigation methods used by household vegetable growers.

\begin{tabular}{ccccccccc}
\hline Irrigation & \multicolumn{2}{c}{ High income } & \multicolumn{2}{c}{ Medium income } & \multicolumn{2}{c}{ Low income } & \multicolumn{2}{c}{ Total } \\
\cline { 2 - 9 } methods & No. & Percent & No. & Percent & No. & Percent & No. & Percent \\
\hline Furrow & 19 & 100 & 44 & 97.77 & 34 & 100 & 97 & 98.97 \\
Flood & 0 & 0 & 1 & 2.22 & 0 & 0 & 1 & 1.02 \\
\hline Total & $\mathbf{1 9}$ & $\mathbf{1 0 0}$ & $\mathbf{4 5}$ & $\mathbf{1 0 0}$ & $\mathbf{3 4}$ & $\mathbf{1 0 0}$ & $\mathbf{9 8}$ & $\mathbf{1 0 0}$ \\
\hline
\end{tabular}


Edossa et al.,

Yusuf and Muluken (2008) found that improved onfarm irrigation practices resulted in better onion and tomato yields around Meki. On the other hand, the authors reported that unimproved traditional irrigation methods led to the application $48 \%$ and $66 \%$ extra water to onion and tomato crop field, leading to water wastage and inefficiency. Paas (2010) also reported similar results where vegetable growers operate under very low water use efficiencies across Haleku and Golba I irrigation schemes around Ziway. The author estimated that the water use efficiencies (CWR/ applied) in different periods of the year in the schemes varied between 0.15 and 0.25 for onion and 0.15 to 0.49 for tomato.
Sci. Technol. Arts Res. J., Jan-March 2014, 3(1): 74-83

Time of Irrigation: Amongthe household $(\mathrm{HH})$ vegetable growers interviewed, $38.14 \%$ indicated that they used to irrigate their vegetable fields both in the morning and in the afternoon. However, 35.05\% replied that they irrigated their vegetable fields in the afternoon. Still $15.46 \%$ responded that they irrigated their fields in the morning whilst $4.12 \%$ irrigated whenever water was available (Table 8). The farmers that irrigated in the morning reportedly assumed that they would use this specific time for the purpose of water-saving techniques and minimize irrigation water loss due to mid-day evaporation. This, in turn, saves fuel costs used for pumping.

Table 8: Timing of vegetable crops irrigation by household growers.

\begin{tabular}{lcccccccc}
\hline \multirow{2}{*}{ Attributes of time of irrigation } & \multicolumn{2}{c}{ High income } & \multicolumn{2}{c}{ Medium income } & Low income & \multicolumn{2}{c}{ Total } \\
\cline { 2 - 8 } & No. & Percent & No. & Percent & No. & Percent & No. & Percent \\
\hline In the morning (1) & 2 & 10.52 & 6 & 13.33 & 7 & 21.21 & 15 & 15.46 \\
At mid-day (2) & 0 & 0 & 1 & 2.22 & 0 & 0 & 1 & 1.03 \\
In the afternoon (3) & 8 & 42.10 & 13 & 28.88 & 13 & 39.39 & 34 & 35.05 \\
When water is available (4) & 0 & 0 & 4 & 8.88 & 0 & 0 & 4 & 4.12 \\
1 and 3 & 6 & 31.57 & 19 & 42.22 & 12 & 36.36 & 37 & 38.14 \\
In the evening & 0 & 0 & 0 & 0 & 1 & 3.03 & 1 & 1.03 \\
1 and 2 & 2 & 10.52 & 0 & 0 & 0 & 0 & 2 & 2.06 \\
1,2 and 3 & 1 & 5.26 & 2 & 4.44 & 0 & 0 & 3 & 3.09 \\
\hline Total & $\mathbf{1 9}$ & $\mathbf{1 0 0}$ & $\mathbf{4 5}$ & $\mathbf{1 0 0}$ & $\mathbf{3 3}$ & $\mathbf{1 0 0}$ & $\mathbf{9 7}$ & $\mathbf{1 0 0}$ \\
\hline
\end{tabular}

This assessment indicated that there an urgent need of developing suitable water management intervention technologies which include, determination of supplemental irrigation for rain-fed vegetables crop production, use of a small devices developed for irrigation scheduling, testing, as well as demonstrations of appropriate technologies for farmers and training farmers through farmers' field schools.

\section{Irrigation Depth, Fixed and Changing Irrigation Intervals}

Irrigation Intervals: A large number of sample growers $(89.58 \%)$ replied that the basis of their vegetable irrigation intervals were determined by the specific crop needs whilst $3.12 \%$ replied that the irrigation intervals were recommended by water users' committee (Table 9).

Table 9: Irrigation intervals used by household vegetable growers.

\begin{tabular}{lcccccccc}
\hline \multirow{2}{*}{ Decision ofintervals } & \multicolumn{2}{c}{ High income } & \multicolumn{2}{c}{ Medium income } & Low income & \multicolumn{2}{c}{ Total } \\
\cline { 2 - 9 } & No. & Percent & No. & Percent & No. & Percent & No. & Percent \\
\hline Crop need & 17 & 89.47 & 42 & 93.33 & 27 & 84.37 & 86 & 89.58 \\
Recommended by committee & 0 & 0 & 2 & 4.44 & 1 & 3.12 & 3 & 3.12 \\
Others & 2 & 10.52 & 1 & 2.22 & 4 & 12.5 & 7 & 7.29 \\
\hline Total & $\mathbf{1 9}$ & $\mathbf{1 0 0}$ & $\mathbf{4 5}$ & $\mathbf{1 0 0}$ & $\mathbf{3 2}$ & $\mathbf{1 0 0}$ & $\mathbf{9 6}$ & $\mathbf{1 0 0}$ \\
\hline
\end{tabular}

Irrigation Depth: Among the sample vegetable growers, $90.91 \%$ across all income groups, replied that they applied enough irrigation water (assumed to be enough) when water immediately touched the furrow basin head (Tras or furrow basin) (Table 10). The farmers reported that they would immediately close (cut off) the water it touched the furrow basin head. Then, they would lead the water to the next furrow. However, Yusuf and Muluken (2008) reported that vegetable growers applied as much as $40-65 \%$ excess water for tomato and onion in Dugidaa area. The authors concluded that it was common to see stagnating water between furrows for several days in household vegetable fields, and farmers' realised that applying excess water would favour disease and pests incidences, waterlogging, root suffocation, which affected yield. Application of excess water incurs unnecessary operational costs, $\mathrm{N}$ nutrient leaching, and creates water logging contributing to additional yield losses. Intense and often inefficient irrigation practice would contribute also to salinization and alkalization of soils of arid and semi-arid regions (Heluf, 1985).

Table 10: Sufficiency of irrigation water depth by household vegetable growers.

\begin{tabular}{lcccccccc}
\hline \multirow{2}{*}{ Sufficiency of irrigation } & \multicolumn{2}{c}{ High income } & \multicolumn{2}{c}{ Medium income } & Low income & \multicolumn{2}{c}{ Total } \\
\cline { 2 - 9 } & No. & Percent & No. & Percent & No. & Percent & No. & Percent \\
\hline Flood over the field (1) & 2 & 10.52 & 3 & 6.66 & 3 & 8.32 & 8 & 8.16 \\
Filing furrow (2) & 17 & 89.47 & 41 & 91.11 & 31 & 91.17 & 89 & 90.91 \\
1 and 2 & 0 & 0 & 1 & 2.22 & 0 & 0 & 1 & 1.02 \\
\hline Total & $\mathbf{1 9}$ & $\mathbf{1 0 0}$ & $\mathbf{4 5}$ & $\mathbf{1 0 0}$ & $\mathbf{3 4}$ & $\mathbf{1 0 0}$ & $\mathbf{9 8}$ & $\mathbf{1 0 0}$ \\
\hline
\end{tabular}

Whenever there is over irrigation, farmers have no ways or method of estimating irrigation water in their vegetable fields. This is because currently, irrigation water is not considered as an economic good. Each furrow irrigation event has extra water exceeding the water holding capacity of the soil so that the risk of water losses through leaching would be frequent. Failure to recognize the economic value of water has led to wasteful and 
Edossa et al.,

environmentally damaging uses of the resource (Paulose, 2002; Yusuf and Muluken, 2008; Seyum, 2011). Managing irrigation water as an economic good is an important way of achieving efficient and equitable use, and encourages conservation and protection of resources.

Among sample growers, $54 \%$ of the growers use fixed irrigation schedule while $45.65 \%$ do not use fixed irrigation schedule for cultivating vegetable and they change their irrigation intervals with crop growth stages (Table 11).

From growers changing their irrigation intervals, $47.84 \%$ depended on the specific crop growth stages, $30.13 \%$ on both prevailing temperature and crop growth stage, and $12.32 \%$ on prevailing temperature (Table 12).

Supplemental Irrigations Practices: The survey indicated that $51.76 \%$ of the vegetable growers practiced
Sci. Technol. Arts Res. J., Jan-March 2014, 3(1): 74-83

supplemental irrigation for vegetable production when faced with shortage of rain during the rainy season as well as after cessation of the rainy season. However, $44.70 \%$ of the growers replied that they did not practiseany supplementary irrigation (Table 13).

As indicated by Edossa (2014) and Edossa et al. (2013b), the long term weather data analysis in the rift valley area of the country showed very frequent dry spells as well as early cessationof rainfallduring the main cropping season, causing large losses in vegetable yields. According to the authors, theses yield losses accounted for $60 \%$ for onion, $54 \%$ for green pepper, $40 \%$ for head cabbage, and $23 \%$ for tomato. Thus, the vegetable growers apparently learned these lessons, which may have induced them to practise supplementing irrigation during the rainy season.

Table 11:Irrigation intervals used by household vegetable growers.

\begin{tabular}{ccccccccc}
\hline \multirow{2}{*}{ Fixed irrigation } & \multicolumn{2}{c}{ High income } & \multicolumn{2}{c}{ Medium income } & \multicolumn{2}{c}{ Low income } & \multicolumn{2}{c}{ Total } \\
\cline { 2 - 9 } & No. & Percent & No. & Percent & No. & Percent & No. & Percent \\
\hline Yes & 12 & 70.58 & 16 & 35.55 & 14 & 46.66 & 42 & 45.65 \\
No & 5 & 29.41 & 29 & 64.44 & 16 & 53.33 & 50 & 54.34 \\
\hline Total & $\mathbf{1 7}$ & $\mathbf{1 0 0}$ & $\mathbf{4 5}$ & $\mathbf{1 0 0}$ & $\mathbf{3 0}$ & $\mathbf{1 0 0}$ & $\mathbf{9 2}$ & $\mathbf{1 0 0}$ \\
\hline \multicolumn{6}{r}{ Significant at $P<5 \%$} & probability level, $\chi^{2}$-value $=6.12, \mathrm{df}=2$ & &
\end{tabular}

Table 12: Growers'reasons for changing of irrigation intervals.

\begin{tabular}{lcccccccc}
\hline \multirow{2}{*}{ Attribute } & \multicolumn{2}{c}{ High income } & \multicolumn{2}{c}{ Medium income } & Low income & \multicolumn{2}{c}{ Total } \\
\cline { 2 - 8 } & No. & Percent & No. & Percent & No. & Percent & No. & Percent \\
\hline None & 1 & 12.5 & 2 & 5.12 & 0 & 0 & 3 & 4.10 \\
Temperature & 1 & 12.5 & 4 & 10.25 & 4 & 16.66 & 9 & 12.32 \\
Crop growth & 4 & 50 & 23 & 58.97 & 8 & 33.33 & 35 & 47.84 \\
1 and 2 & 1 & 12.5 & 10 & 25.64 & 11 & 45.83 & 22 & 30.13 \\
1,2 and 3 & 1 & 12.5 & 0 & 0 & 1 & 4.16 & 2 & 2.73 \\
\hline \multicolumn{1}{c}{ Total } & $\mathbf{8}$ & $\mathbf{1 0 0}$ & $\mathbf{3 9}$ & $\mathbf{1 0 0}$ & $\mathbf{2 4}$ & $\mathbf{1 0 0}$ & $\mathbf{7 3}$ & $\mathbf{1 0 0}$ \\
\hline \multicolumn{7}{c}{ Significant at $P<\mathbf{1 \%}$ probability level, $\chi^{2}$-value $=24.00, \mathrm{df}=10$} &
\end{tabular}

Table 13: Use of supplementary irrigation (SI) practices during the rainy season.

\begin{tabular}{ccccccccc}
\hline \multirow{2}{*}{$\begin{array}{c}\text { Application of } \\
\text { SI }\end{array}$} & \multicolumn{2}{c}{ High income } & \multicolumn{2}{c}{ Medium income } & \multicolumn{2}{c}{ Low income } & \multicolumn{2}{c}{ Total } \\
\cline { 2 - 9 } & No. & Percent & No. & Percent & No. & Percent & No. & Percent \\
\hline None & 0 & 0 & 0 & 0 & 3 & 12 & 3 & 3.52 \\
Yes & 9 & 47.36 & 19 & 46.34 & 16 & 64 & 44 & 51.76 \\
No & 10 & 52.63 & 22 & 53.65 & 6 & 24 & 38 & 44.70 \\
\hline Total & $\mathbf{1 9}$ & $\mathbf{1 0 0}$ & $\mathbf{4 1}$ & $\mathbf{1 0 0}$ & $\mathbf{2 5}$ & $\mathbf{1 0 0}$ & $\mathbf{8 5}$ & $\mathbf{1 0 0}$ \\
\hline
\end{tabular}

Availability, scarcity and competition for irrigation water

Availabilityof Irrigation Water: Among the sampled vegetable growers, $63.91 \%$ responded that irrigation water availability was not a problem. This response was obtained particularly in Dugidaa and Boora districts where ground water could be struck at shallow to very shallow depths in farm fields.

Scarcity of Irrigation Water: The scarcity of irrigation water depends on the farm distance from water sources, and in particular if the sources are of communal schemes; there is always water scarcity among users, up-streams and down streams due to unplanned use, and transplanting,which results in overlapping of critical growth stages. Water budgeting and planning crop planting are important for farmers using communal schemes like Fantalle irrigation scheme. However, farmers using ground water for irrigationdid not report facing water shortages. Such farmers often pumped as much as they wanted, which may result in depletion of ground water in the future.

Competition for Irrigation Water:Vegetable growers indicated that there was a serious competition among water users when irrigation water sources are from same sources like rivers and communal schemes. For example, household growers of Qawwa Haara Mirqassa (Boolee, Merti) peasant association residing in the UAAIE farm units have problems of water distribution. Similarly, vegetable growers using Haleku and Dodicha irrigation schemes in Dugidaa district faced water shortage during the dry seasons. This was because household irrigated crops production was not supported,i.e., no planning of water to be used and crops to be produced. Additionally because water is free, most government and private commercial farms located in the CRV area use excess irrigation water. Stagger planting and water saving could help this group so that overlap of critical crop water requirements might be avoided. Generally, there exists severe competition and exploitation of irrigation waters in 
Edossa et al.,

the CRV among private investors and smallholder farmers, industries (like Soda ash), which would lead to reductions of inflow water (rivers like Meki, Modjo and Katar) starting from end of September. Padowski and Jawitz, (2009) reported that groundwater mining, where water resources are removed at rates exceeding that at which they are recharged led to dramatic drops in water table levels in India, the United States, China, and Mexico, threatening water supplies, the health of local ecosystems, and future food security. Similarly, the survey results of this study revealed that water abstraction is done without the basic understanding of the complex hydrological and hydro-geological system and the fragile nature of the Rift Valley Ecosystem (Ayenew, 2007).
Sci. Technol. Arts Res. J., Jan-March 2014, 3(1): 74-83

Perceptions on Environmental Situations due to Irrigation

Awareness on Potential Environmental Problems Created due to Irrigation: There is awareness among all household vegetable growers interns of pollution of some lakes like Kokaa (Seyum, 2011); however,proper management of water resources has not yet been exercised.Thereare no institutions supporting smallholder irrigation except some NGOs. Thus, all household vegetable growers are currently managing their irrigation water by intuition. Among sample household growers, $63.63 \%$ perceive that there are potential environmental problems caused due to irrigation whilst $36.36 \%$ replied that there are no potential environmental problems caused due to irrigation (Table 14).

Table 14: Awareness on potential environmental problems created due to irrigation as perceived by smallholder vegetable growers.

\begin{tabular}{ccccccccc}
\hline \multirow{2}{*}{ Attributes } & \multicolumn{2}{c}{ High income } & \multicolumn{2}{c}{ Medium income } & \multicolumn{2}{c}{ Low income } & \multicolumn{2}{c}{ Total } \\
\cline { 2 - 9 } & No. & Percent & No. & Percent & No. & Percent & No. & Percent \\
\hline Yes & 11 & 61.11 & 31 & 65.95 & 21 & 61.76 & 63 & 63.63 \\
No & 7 & 38.88 & 16 & 34.04 & 13 & 38.23 & 36 & 36.36 \\
\hline Total & $\mathbf{1 8}$ & $\mathbf{1 0 0}$ & $\mathbf{4 7}$ & $\mathbf{1 0 0}$ & $\mathbf{3 4}$ & $\mathbf{1 0 0}$ & $\mathbf{9 9}$ & $\mathbf{1 0 0}$ \\
\hline
\end{tabular}

Although, irrigation has contributed significantly to poverty alleviation, food security, and improving the quality of life for rural populations, the sustainability of irrigated agriculture both economically and environmentally is being questioned (FAO, 1997). Besides health problems, the increased dependence on irrigation has not been without its negative environmental effects; irrigation has possible potential for causing: increased erosion, pollution of surface water and groundwater with agricultural chemicals, deterioration of water quality, and increased nutrient levels in the irrigation and drainage water, resulting in proliferation of aquatic weeds and eutrophication of water in irrigation canals and downstream waterways (FAO, 1997).

Many local reports are available (EPA,1998) and Zinabu (1998) that improper mmanagements of irrigation schemes in the middle Awash dry areas resulted in salinization, leading to the abandonment of hundreds of irrigable farm lands, and the spread of some water-related diseases, particularly in the Rift Valley region of the country.

\section{On-farm Irrigation Water Related Challenges}

One hundred percent of the interviewed vegetable growers replied that they faced different problems while producing vegetables using irrigation. The major on-farm existing irrigation water related problems are salinity, waterlogging, soil erosion and degradation, sedimentation, build-up of pests and diseases. All growers perceived that waters from most boreholes (aquifers) around Lake Ziway shore are salty since they observed that white crustsremain on the soil after irrigation in the side furrow, which caused the abandonment of crop lands. Water pollutions due to the intensive use of agrochemical by farmers and commercial agricultural investors are also evident in the area. Thus, water quality problems should be viewed from natural and artificial causes. Various reports indicated that water sources used for irrigation in the CRV have quality problems due to either natural sources from the underlining rocks, sodium and $\mathrm{Ca}$ containing rock minerals, and owing to artificial causes due to negligence of concerned organizations and private companies to apply EPA environmental proclamations, guidelines, and directives.

Natural Problem:Some of the specific limitations of water quality from various sources in CRV (Modjo River Kokaa Lake, Borehole around Ziway, Ziway Lake, etc) were identified by research scholars such. Surafel (2007) found that sample of ground water from Dugdaa Boorraa district was not fit for irrigation as it did not meet water quality standard for this purpose due to high salt contents, chloride toxicity, too high $\mathrm{pH}$, and high contents of bicarbonate and calcium ions. Behailu (2007) also found that the $\mathrm{pH}$ of most of the water samples from around Modjo River varied from 7.7 to 8.3 , with the dominant content of bicarbonate. The author concluded that the water of Modjo river area has an alkaline $\mathrm{pH}$. Furthermore, Behailu (2007) found that the amount of total dissolved solids (TDS) in sample surface water of Modjo River was $1332 \mathrm{mg} \mathrm{L}^{-1}$, indicating that it is brackish water (with TDS of 1000-10000 ppm) and not suitable for irrigation for the lower basin vegetable growers.

Artificial Problems: Water quality problems were a major a bottleneck for vegetable growers around Koka Lake, Modjo River. Growers explained that pollution of river, stream and lake waters were mainly due to industrialization going on in the upstream and inadequate waste water treatment by the industries or factories concerned (Behailu, 2007).Local residents estimated at 15000 use the Koka Lake (Seyum, 2011). However, due to the present situation, the Koka lake-heavily polluted and the people have no alternative to resort to for fresh water supply, and are suffering from poor sanitation and water-borne diseases that are resulting from drinking the toxic water(Seyum, 2011; Al Jazeera, 2009). A sample key informant of vegetable growers said that Koka Lake is "Green in the morning", and "Red in the afternoon"; adding that it is not fit for irrigated vegetable production. Behailu (2007) and Al Jazeera, (2009) found that the physical characteristics of the samples collected from surface water showed that the Modjo River has green and dark green colour, high turbidity and a lot of suspended material due to industrial and sewage wastes disgorged 
Edossa et al.,

into it. The results of water samples collected from the Modjo River, boreholes, and lakes showed that Modjo River is highly polluted (Behailu, 2007).

Soil Fertility and Sustainability of Irrigationas Perceived by Smallholder Farmers

From the sampled vegetable growers, $88.77 \%$ responded that, although they feel irrigation increases cropping intensity and nutrient removal from the soil, they had the feeling that irrigation is sustainable. The farmers added that the increased removal of nutrients from the soil due to irrigation could be countered or compensated for by application of fertilizers, crop residues, and animal to the soil to sustain productivity of the land.

Pumping up water for irrigation throughout the year from lakes, rivers, and aquifer free of charge may put the sustainability of irrigation and land under pressure. Irrigation under delicate environments, carbonated ground
Sci. Technol. Arts Res. J., Jan-March 2014, 3(1): 74-83

water, poor irrigation efficiency, heavy dose of fertilizers, poor nutrient management, and deforestation, would lead to un-sustainability of irrigation development. Most growers replied that various environmental problems were created due to development of irrigations in the CRV (Table 15).

Based on study made on the lake Koka and the livelihoods of the local communities, Seyoum (2011), reported that there was a complete lack of institutional coordination, environmental awareness, and stakeholder participation in environmental management. To create sustained environmental awareness and curb degradation and depletion of the natural resource base in the study area, establishing partnerships among varied stakeholders and actors, improving transparency, fostered stakeholder participation, and effective local management through empowerment of the local community would be a perquisite.

Table 15: Environmental problems created due to irrigation development as perceived by household vegetable growers.

\begin{tabular}{|c|c|c|c|c|c|c|c|c|}
\hline \multirow{2}{*}{ Environmental problems } & \multicolumn{2}{|c|}{ High income } & \multicolumn{2}{|c|}{ Medium income } & \multicolumn{2}{|c|}{ Low income } & \multicolumn{2}{|c|}{ Total } \\
\hline & Number & Percent & Number & Percent & Number & Percent & Number & Percent \\
\hline None & 0 & 0 & 1 & 3.125 & 0 & 0 & 1 & 1.56 \\
\hline Environmental degradation (1) & 0 & 0 & 1 & 3.125 & 0 & 0 & 1 & 1.56 \\
\hline Risk of erosion (2) & 0 & 0 & 1 & 3.125 & 0 & 0 & 1 & 1.56 \\
\hline Risk of degradation (3) & & 0 & & & & & & \\
\hline Low fertility (low organic matter) (4) & 1 & 10 & 7 & 21.875 & 4 & 18.18 & 12 & 18.75 \\
\hline Risk of rising water table (5) & 0 & 0 & 1 & 3.125 & 0 & 0 & 1 & 1.56 \\
\hline Seepage (6) & -- & -- & -- & -- & -- & -- & -- & -- \\
\hline Water logging (7) & -- & -- & -- & -- & -- & -- & -- & -- \\
\hline Development of salinity (8) & 1 & 10 & 1 & 3.125 & 4 & 18.18 & 6 & 9.37 \\
\hline Development of siltation (9) & 0 & 0 & 2 & 6.25 & 1 & 4.54 & 3 & 4.68 \\
\hline Ground and surface water pollution(10) & -- & -- & -- & -- & -- & -- & -- & -- \\
\hline Disease and pest occurrence (11) & 5 & 50 & 16 & 50 & 10 & 45.45 & 31 & 48.43 \\
\hline $2,4,11$ and 12 & 1 & 10 & 0 & 0 & 0 & 0 & 1 & 1.56 \\
\hline 11 and 12 & 0 & 0 & 1 & 3.125 & 0 & 0 & 1 & 1.56 \\
\hline 5 and 12 & 0 & 0 & 1 & 3.125 & 0 & 0 & 1 & 1.56 \\
\hline 6,11 and 12 & 1 & 10 & 0 & 0 & 0 & 0 & 1 & 1.56 \\
\hline 5,7 and 9 & 0 & 0 & 0 & 0 & 2 & 9.09 & 2 & 3.12 \\
\hline 4 and 7 & 0 & 0 & 0 & 0 & 1 & 4.54 & 1 & 1.56 \\
\hline All $(1-11)$ & 1 & 10 & 0 & 0 & 0 & 0 & 1 & 1.56 \\
\hline Total & 10 & 100 & 32 & 100 & 22 & 100 & 64 & 100 \\
\hline
\end{tabular}

Environmental Degradation: The situation of environmental degradationin the CRV area was reported by many scholars such as Paulos, (2002), Paulos et al., (2002), Jansen et al., (2007), Hengsdijk and Jansen (2006); and Zinabu, (1989 and 1998) mainly due to expansion of irrigation and farmlands.

Low Fertility (with Low Organic Matter): Low fertility (with low organic matter) is due to high cropping intensity, removal of crop residues, heavy radiation during most of the months of the year, heavy wind speed with wind erosion particularly during the dry season, absence of agro forestry practices.

Development of Salinity: Water sources from boreholes full of salt are affecting vegetable production fields. This situation is reported by many scholars (Paulos et al., 2002; and Tilahun and Paulos, 2004). Surafel, (2007) who described that sample of ground water from Dugda Boorraa districts was not fit for irrigation due to high salinity problems, chloride toxicity, too high $\mathrm{pH}$, bicarbonate, and calcium ions. Behailu, (2007), also found that the $\mathrm{pH}$ of the water samples obtained from most of the water samples around Modjo River varied from 7.7 to 8.3 with bicarbonate being dominant in the sample waters.
The author concluded that the water of Modjo area has an alkaline $\mathrm{pH}$. Hengsdijk and Jansen, (2006) citing Gashaw, (1999) also described that the total dissolved solids in the Bulbula River (outflow from lake) and Meki River were similar $\left(300-400 \mathrm{mg} \mathrm{L}^{-1}\right)$, the salt concentration of the water in the Ketar River was less than $200 \mathrm{mg} \mathrm{L}^{-1}$; the predominant ions in the Meki and Ketar River were calcium and bicarbonate with Bulbula River and Lake Ziway having a relative abundant sodium and bicarbonate.

Development of Siltation: Lack of buffer zone along lake shore and absence of agro forestry, and soil conservation in the upstream contributed to siltation of all lakes (Koka, Ziwai, etc) and heavy damaging erosion in the CRV in particular over flooding of Wonji and Adaama towns.

Developments of Diseases and Pest Occurrence: Vegetable growers perceived that among environmental problems created due to irrigation development, high cropping intensity, mono-cropping and continuous cropping of either onion or tomato made continuous use of intensive agrochemicals. Thus $48.43 \%$ of the respondent replied that diseases and pest occurrences were a few of the problems in irrigated agriculture. 
Edossa et al.,

However, in order to minimize diseases and pest pressures, all growers use crop rotations and pesticides for diseases and pest control. As reported by Getachew and Mohammed (2012), some vegetable growers mix insecticide and fungicide and spray as high as 16 times in a wet season and as high as 8 times during a dry season whilst the recommendation is a maximum of 5 times when the worst infestation occurs. Warm season cultivation after January requires more sprays than cool season transplanting (September). The longer life cycle of the crops like onions entail more number of sprays per season, which one of the major reasons for growers to prefer early maturing onion varieties. This indicates that there are high pesticides residues in soil and on the surfaces of leafy and fruit vegetable produces from the Central Rift Valley areas of the country. Additionally, the cost of chemicals constitutes one of the highest proportions of the total cost required for tomato and onion production next to labour cost (Getachew and Mohammed, 2012)..

\section{CONCLUSIONS}

Based on field observations, problem analyses of irrigation management practices of different vegetable production systems in the Central Rift Valley, existing problems and gaps were identified. Current tomato and onion main agronomic practices were assessed. Constraints of irrigation water management in vegetable crops production were diagnosed and a series of problems related to agronomic and irrigation water management's practices were identified.These led to further identification of agronomic and water related research domains in vegetable production in the Central Rift Valley of the country.Smallholder household irrigation is initiated and financed by individual farmers, mostly without technical support. Smallholder farmers irrigate their fields using buckets, treadle pumps or small motorized pumps from nearby water sources such as shallow wells, streams, lakes, small reservoirs, etc.The farmers irrigate small areas; typically some irrigate on average less than a hectare of land. The farmers produce a number of vegetable and supply for the local market. Vegetable production in the area is a source of income for thousands of smallholder farmers. However, the irrigation practices and water management of the farmers are mostly based on intuition, with no scientific support from the extension system. Among the problems, absence of available seasonal supplementary and full irrigation packages, absence of extension package for irrigation water management, and lack of knowledge support system, and absence of defined water management institutions at growers' level are the major ones. Vegetable growers should be provided with skilled irrigation and water management frontline development workers (DAs). On the other hand, water loss is extremely high due to over-irrigation that might be associated with leaching of $\mathrm{N}$; many thousands of hectares of land are lost every year mainly due to development of secondary salinization. Thus, there should be smallholder irrigation support office (vegetable irrigation taskforce) or institution in Ethiopia for the development of proper household agricultural water and land management practices for enhanced and sustainable irrigated vegetable production in the study area.

\section{REFERENCES}

Abiti Getaneh(2007). Comparison of Different Irrigation Scheduling Methods for Onion (Allium cepa L.) Seed
Sci. Technol. Arts Res. J., Jan-March 2014, 3(1): 74-83

Production and under Unfertilized Conditions at Melkassa, M.Sc. Thesis, Haramaya University.

Adugna Gessesse (2009). Analysis of Fruit and Vegetable Market Chains in Alamata, Southern Zone of Tigray: The Case of Onion, Tomato and Papaya. M.Sc. Thesis, Haramaya University, Pp.114.

Allen, R.G., Pereira L.S., Raes D., and Smith M. (1998). Crop Evapotranspiration (Guidelines for Computing Crop Water Requirements), FAO, Irrigation and Drainage Paper № 56, FAO, Rome, Italy.

Al Jazeera (2009). People and Power, Al Jazeera Television, the Green Lake http://english.aljazeera.net/programmes/ peopleandpower/2009/02/200922114211921697.html(20 09), Date Accessed, 15 April 2011.

Ayenew, T. (2007). Water management problems in the Ethiopian Rift: Challenges for Development. Journal of African Earth Sciences 48: 222-236.

Behailu Berehanu (2007). Impact of Industries and Urbanization on Water Resource in ModjoRiver Catchment. M.Sc thesis, Addis Ababa University, Pp 104

Birhanu Kibebew (2006). Deficit Irrigation Scheduling of Drip Irrigated Tomato at AwashMelkassa, M.Sc Thesis, Haramaya University, Ethiopia.

Birhanu, K. and Tilahun, K.(2010). Fruit yield and quality of drip-irrigated tomato underdeficit irrigation. African Journal of Food, Agriculture, Nutrition and Development 10(2): 2139-2151.

Bos M.G., Kselik, R.A.L., Allen,R.G. and Molden,D.J. (2009). Water Requirements forlrrigation and the Environment. Joint publication International: Institute for GeoInformation Science and Earth, Observation, ITC; Wageningen UR; University of Idaho Research and Extension Center; International Water Management Institute, IWMI; Springer Science.

Carter R., and Kerstin Danert, 2006. Planning for Small-Scale Irrigation Intervention,FARM-Africa Ethiopia.

CIMMYT. (1988). From Agronomic Data to Farmer Recommendation: An Economic TrainingManual. Mexico, DF. Pp.79

Desta Beyera. (2004). Impact of Community Managed Irrigation on Farm Production Efficiencyand Household Income: The cases of Weliso and Wenchi Districts of Oromia Regional State, M.Sc Thesis, Haramaya University.

\section{East Showa Zone MoARD Office Report, 2011}

Edossa Etissa., Nigussie Dechassa., Tena Alamirew., Yibekal Alemayehu and LemmaDesalegne, (2013a). Household Fertilizers Use and Soil Fertility Management Practices in Vegetable Crops Production in the Central Rift Valley of Ethiopia. Science, Technology and Arts Research Journal2(4): 47-55.

Edossa Etissa., Nigussie Dechassa., Tena Alamirew., Yibekal Alemayehu and LemmaDesalegne(2013b). Analysing Rainfall Variability, Evaluation of Rain-fed Vegetable Crops Production and Planning Supplementary Irrigations: The Case of Melkassa Area, Central Rift Valley of Ethiopia. Paper Presented at the International Conference on Integrated Agriculture and Food Security and Adaptation to Climate Change (IAFSACC-2013), 46June, 2013,Ambo University, Ethiopia (In Press).

Edossa Etissa., Nigussie Dechassa, Tena Alamirew, Yibekal Alemayehu and Lemma Dessalegne (2013c). Monitoring of Small Scale Vegetable Crops Production Packagesin 


\section{Edossa et al.,}

the Central Rift Valley of Ethiopia: Challenges for Researchers-Extensions-Growers. Crop Science Society of Ethiopia (CSSE). Sebil Vol. 15: Paper Presented on the $15^{\text {th }}$ Biannual Conference of Crop Science Society of Ethiopia,9-10 May2013, Addis Ababa, Ethiopia.

Edossa Etissa, Nigussie Dechassa, Tena Alamirew, Yibekal Alemayehu and Lemma Dessalegne(2013d). Production Characteristics and Field Management Practices of Household Vegetable Crops Production System in the Central Rift Valley of Ethiopia.Paper Presentedat $4^{\text {th }}$ Biannual Conference of Ethiopian Horticultural Science Society, 12-13 April 2013, Ambo, Ethiopia.

Edossa Etissa(2014). Irrigation and Nutrient Management Practices in Vegetable Crops Production, and Response of Tomato (Lycopersicon esculentum M.) to Integrated Nutrients Supply and Irrigation Regimes under Different Growing Conditions in the Central Rift Valley of Ethiopia. A PhDThesis Dissertation, School of Graduate Study, Haramaya University, Haramaya, Ethiopia, pp 432

FAO (1997). Irrigation potential in Africa: A basinApproach, FAO Land and Water Bulletin 4, FAO Land and Water Development Division.

Getachew Legesse., Mohammed Hassena(2012). Assessment of Vegetables Value chain inCentral Rift Valley, Ethiopia. Oxfam America, Horn of Africa Regional Office, Addis Ababa, Ethiopia, July 2012 (Unpublished).

Gulilat Birhane (2002). Present and future water resources development in Ethiopia related toresearch and capacity building pp 11-21. In: P.G.McCornick, A.B. Kamara and Girma Tadesse (Eds). Integrated water and land management research and capacity building priorities for Ethiopia Proceedings of a MoWR/EARO/IWMI/ILRI Workshop held at ILRI, Addis Ababa, Ethiopia.

Heluf G. Kidan. (1985). Investigation on salt -affected soils and irrigation water quality inMelkaSedi-Amibara Plain, Rift Valley Zone of Ethiopia, M.Sc Thesis. Addis Ababa University, Addis Ababa.

Hengsdijk H. and Herco Jansen (2006). Agricultural Development in the Central Ethiopian RiftValley: A deskstudy on Water-related issues and Knowledge to Support a Policy Dialogue, Wageningen, Plant Research International, the Netherlands, Note 375.

Jansen, H., Hengsdijk, H., Legesse, D., Ayenew, T., Hellegers, P., Spliethoff, P. (2007). Landand Water Resources Assessment in the Ethiopian Central Rift Valley. Alterra, University, Alterra Report 1587.

Lemma Desalegn. (2004). Tomatoes. Research experiences and production prospects, Researchreport No. 43. EARO. Addis Ababa, Ethiopia.

Lemma Desalegn and Shimelis Akililu (2003). Research Experiences in Onion Production:Research Report No. 55. EARO, Addis Ababa, Ethiopia .

Lemma Desalegn. (2002). Major Vegetable Crop Varieties and Their Production Practices,2002. Vegetable IPM Project (EARO/ICIPE) EARO, Addis Ababa, Ethiopia.

Mekuria, Tafesse. (2003). Small-Scale Irrigation for Food Security in Sub- Saharan Africa.CTA Working Document Number 8031.

Mengistu Assefa (2008). Socio-economic assessment of two small-scale irrigation schemes inAdaamii Tullu Jido Kombolcha Woreda, Central Rift Valley of Ethiopia, M Sc Thesis, Wageningen University. pp 102.
Sci. Technol. Arts Res. J., Jan-March 2014, 3(1): 74-83

Paas, W. (2010). Two Small Scale Irrigation Systems in the Central Rift Valley of Ethiopia:The Way It Is and The Way Forward, Wageningen University, Pp. 47.

Paulos Dubale (2002). Present and Future Trends in Natural Resources Management inAgriculture: An overview, pp 29-37. (In): P.G.McCornick, A.B. Kamara and Girma Tadesse (Eds). Integrated water and land management research and capacity building priorities for Ethiopia Proceedings of MoWR/EARO/IWMI/ILRI Workshop held at ILRI, Addis Ababa, Ethiopia 2-4 Dec 2002.

Paulos Dubale, Michael Menkir, Moltot Zewdie and Lijalem Zeray (2002). Agriculture, Irrigation and Drainage Research in the Past and the Future, pp. 38-45. (In): P.G.McCornick, A.B. Kamara and Girma Tadesse (Eds). Integrated Water and Land Management Research and Capacity Building Priorities for Ethiopia Proceedings of a MoWR/EARO/IWMI/ILRI International Workshop held at ILRI, Addis Ababa, Ethiopia 2-4 December 2002.

Seyoum T. Akele, (2011). The practice and challenges of lake management in Ethiopia: Thecase of Lake Koka, Master of Science Thesis in Environmental Science, Swedish University of Agricultural Sciences, SLU, Uppsala, Sweden, pp 115.

Tafesse Bikila, (2007). The Income Contribution of Ziway Lake to Smallholder Farmers andFishing Households and its Implications for the Sustainability of the Water and Fish Resources, M.Sc Thesis, Haramaya University, 116.

Tesfaye Shiferaw. (2008). Socio-ecological Functioning and Economic Performance of Rain-fed farming Systems in Adami Tulu Jido Kombolcha District, Ethiopia. Agroecology Masters Program Norwegian University of Life Sciences. pp 68.

Tilahun H. and Paulose D. (2004). Results to Date and Future Plan of Research on Irrigation andlts Impact. Workshop on Impact of Irrigation on Poverty and Environment, Workshop Proceeding, April 2004.

Worku Burayu, (2006). Conservation tillage options for sustainable crop production systems inthe semi-arid and sub-humid Oromia, PhD Thesis, Kasetsart University.

Yusuf Kedir and Muluken Philipos (2008). Scaling out of improved irrigation watermanagement technologies through demonstration on farmers field of $F R G$ members, pp 59-66. FRG Completed Research Report 2007. FRG Project, Melkassa Agricultural Research Centre.

Zinabu, Gebremariam (1998). Human Interactions and Water Quality in the Horn of Africa. (In):Science in Africa: Emerging Water Management Issues. Proceedings of a Symposium held in February 1998 in Philadelphia. American Association for the Advancement of Science (AAAS) African program, published online at: http://www.aaas.org/international/africa/ewmi/zinabu.htm.

Zinabu Gebremariam, (1989). Water Resources and Fisheries Management in the Rift ValleyLakes. SINET:Ethiopian Journal of Science 12(2): 95-109. 